\title{
Legal Justice and Historical Aspects of the Appearance of Criminality
}

\author{
Mevledin Mustafi \\ Doc.Dr. of criminal and legal sciences and \\ a specialist in the field of customs crime, Macedonia
}

Abstract

Criminality as a negative and dangerous social phenomenon presents a social occurrence manifested in different forms during the entire course of human history. Historically, it has been proved that since the ancient times of existence of human society, since primitive community, there have been not only deviations, but also other forms of excessive behavior through breaking the rules, values and social relations of life where they existed. However, the forms of breaking such behavioral rules and the manner of reaction towards these behaviors have changed during the course of development of human communities in accordance to economic ties and as a result also to those cultural. With time passing and the emergence of classes in societies, as well as due to the influence of economic conditions in the life of all members of organized society within a state, crime became a more massive social phenomenon. Thus, in order to successfully develop the fight against it, within class societies emerged a special instrument: the law through which certain behaviors were regulated.

Keywords: Legal Justice, Historical Aspects, Appearance of Criminality

\section{The general approach to criminality as a negative and dangerous social phenomenon}

Every human society within its positive-legal norms incriminates certain activities, which by "public governance" institutions give them the character of dangerous social activities and foresee sanctions in cases were the same are breached. Crime is a social occurrence which in different ways manifests negative activities and in a social context produces consequences. .1 Such a negative activity is manifested primarily against material goods and values. Despite these material goods, subject to attacks from criminal activities are also the social values in the context of moral perceptions at a given social environment. These also include the different political, cultural and other social values, generated by the society in the process of its development. When all these material goods and values fall under criminal attacks, this activity leaves destructive and negative implications. ${ }^{2}$

\section{Being a unique social phenomenon, crime has its roots, reasons, history and manifests certain effects}

Being a unique social phenomenon, crime has its roots, reasons, history and manifests certain effects depending on the circumstances and cases, in different fields of life, such as economy, politics, justice, morality, culture etc. Due to its destructive nature, crime has always produced fear, insecurity and horror among citizens, and at the same time increased interest in it. Therefore, in all phases of development of human societies a special interest was shown about the nature, reason and motives of the crime as well as the often tragic consequences and in finding ways for its prevention. ${ }^{3}$

Since the beginning of the $20^{\text {th }}$ century it becomes increasingly clear that crimes committed by adults and juveniles are not only criminal-legal concepts. These two phenomena represent complex social occurrences the fight of which needs comprehensive organization of the society and different sciences; hence the legal-criminal treatment of these phenomena is related to this issue. Criminal and sociological researches have contributed in the opinion that crime is a phenomenon conditioned by the society, whereas the criminal, to a greater or lesser extent, is a result of certain social influences and rapports. ${ }^{4}$ Earlier views and opinions on crime encompass its road toward development, beginning from the earlier opinions of philosophical and theological nature on criminality all the way to the opinions of legal-penal schools on criminality. In this

\footnotetext{
1 Sahiti Ejup. E drejta 1/1995, Prishtina, p. 13-14.

2 Milutinoviq, Milan. Kriminologjia, Rilindja, Prishtina, 1982, p. 297-298.

3 Halili, Ragip. Kriminologjia, Prishtina, 2008, p. 10.

${ }^{4}$ Latifi, Vesel. E drejta 1/1997, Prishtina, p. 29. 
sense security issues gain another new meaning and importance, essentially in managing and efficient operation of the security system subjects in modern conditions. Only educated and well trained personnel can create transparent, democratic and communicative subsystems with clear objectives and defined strategies for carrying out duties in the process of modernization. ${ }^{1}$

\section{A process needed to be based on theoretical and scientific knowledge as legal justice}

This process needs to be based on theoretical and scientific knowledge, whose concrete and practical operability needs to ensure an acceptable role of the system subjects. This is in the reciprocal and mutual interest for solving security issues. Security is not only an issue for the organs of security, but also for all the citizens. For this reason the security mechanisms need to have a respectable place in the society and this can be achieved only through acting based on the scientific and professional knowledge and achievements.

To improve the institutions and its laws, by making them just, society members may freely discuss and present their legitimate requests. Everyone can freely present arguments for their rational positions. Those who are able to think critically always have an opinion on the society, its values and the lack of values, problems and possibilities for rational solution of the same. It would have been ideal if the critical thinking through its views on society and its institutions and laws would have been respected during the course of solving issues that preoccupy the society. Obviously, this is opposed by the policy of pseudo-intellectuals, who prefer to keep their positions, couches, good salaries and other benefits. In the interest of proper functioning of institutions and laws, according to which they function, which is also in the interest of all members of the society, it is necessary to voice a critical opinion. It should always be ready for free discussions on institutions and laws and to present its legitimate demands, aiming at the enhancement of institutions. ${ }^{2}$

\section{The informative revolution, despite the provided benefits, still has its negative aspects}

Great and fast changes in the field of information technology of many modern countries and the application of this technology in the automation of work processes in all spheres of economic and social life represent a real phenomenon today. As part of this, the development of information technology and permanent perfection of the computer's operation in different spheres of activities of natural and legal persons, from the production and circulation of goods and services all the way to national defense and security in a broader sense, have caused that a certain category of irresponsible groups and individuals, through their illegal behavior by using their computers and its components, earn illegal profits for themselves or others. At the same time, through their activities, they cause material damage to natural persons, institutions and to the society in general.

The modern society today is using the greatest achievements of technical-technological development, which are followed by the fast expansion of information technology and the automation of working processes in all spheres of economic and social life. This development, in one hand has brought great ease to the modern society, whereas on the other hand, the premeditated misuse of these technological achievements has created a number of problems and risks to the society in general.

Today, the information technology touches every aspect of life regardless of its position in the globe. Despite the benefits provided by the information revolution, it also has its negative aspect.

\section{The educational concept oriented towards the future}

The educational concept oriented towards the future is a very strong instrument for adapting the dynamism of organizational security structures towards future challenges. Despite the development of the educational system in accordance with the demands and needs of modern society, the equipment with material and technical means, the use of the scientific

\footnotetext{
1 Dr.Selmani Bashkim, Krimi i organizuar dhe terrorizmi - Univeristeti parë privat ,FON”-Shkup 2010
}

2 Dr. Selmani Bashkim Kriminologjia dhe penologjia p-12-21. Prishtina, 2014 
achievements and the use of information and communication means, of a crucial importance is also the management system, especially in performing actions in complex security situations. Only a managing system based in scientific achievements and in the application of modern concepts, principles, methods, tactics and techniques can bring success to operational strategic duties in achieving specific objectives, which are a target of democratic security forces' vision. ${ }^{1}$

On the other hand, what are the researchers of this scientific field doing to eliminate and alarm that exactly the ignorance towards these criminal action techniques influences the deterioration of public opinion at times when wealth deviates and draws in itself every person. Of same importance today is also to identify crime, because often both us and our children may be a part of a certain crime if we don't study it and educate people and the young generations about the risk threats from the organized crime in the Albanian modern society.

\section{The Albanian society is more than ever touched from crime and criminality}

The Albanian society is more then ever touched by crime and criminality, and if this is kept silent as it was done until now, crime becomes everyday life to the point where people just by listening to the news know that every sentence starts and ends with crime and criminality. Historical tracking among Albanians has shown that the tendencies and the authors of the crime had usually come from the less educated and less developed people and parts of society. The question that arises is whether today this is still a practice! I can guarantee you that that is not the practice today. Exactly when the psychology of thinking among Albanians have changed a lot, criminality has broken these postulates and we can responsibly conclude that today we have a different momentum, when in particular educated and skilled people commit crimes in different criminal fields, starting form high officials, all the way to their drivers. I stress this because people and officials often, unconsciously and unwillingly enter the darkness of the bunker called greed for wealth without knowing what is hidden in that hermetically sealed bunker.

It is also important that leadership is also a profession that, besides knowledge, demands scientific preparation for building interpersonal relations within the state organizational structures in order to familiarize the public with the potential dangers. This occurs in order to adapt to the demands of the society without the use of corruption and the conditional criminal way for performing an administrative-institutional service.

Viewed from this perspective, we can conclude that a precondition to this is the building of such relations within security structures, which will enable their development in accordance with the principles of equity, tolerance, patience and abilities. This implies the respect towards the leadership philosophy which includes political, judicial, strategic, tactical and other components. In the events of drafting the operational global plans, especially in cases of operational measures, that what highlights is the knowledge about the matter at hand by managing structures. In this way we can follow the level of the implementation of objectives and give the necessary counsels for action, which then will help the orientation of the efficient actions. Each security system of a society takes care for the implementation of duties for which is held responsible.

\section{Conclusion}

The modern management system requires the achievement of determined objectives according to the mutual strategy and the security policy and strategy in the war against criminality. Each death case today would be much more complicated to be solved unless we didn't have sophisticated methods and techniques of forensic expertise. For this reason, the managing services in all hierarchical levels of organization and of authorizations and responsibilities have a crucial role in building and developing relations with the social community in rapport to individual-state and society.

If the relations between elements of the managing system are at a satisfactory level, then also the relations between different levels of forces against the state organized crime would be in accordance with the predetermined objectives from the legal state mechanisms. This can be achieved only within those structures which posses developed organizational and strategic components. Through special methods, expert personnel and higher responsibility they would attempt to eliminate evil thoughts which devour more and more the Albanian society, regardless of the territories they live today. Also the security system, through a series of bearers and entities aims at fulfilling the duty and implementing the duties for achieving,

${ }^{1}$ Dr.Selmani Bashkim, Krimi i organizuar dhe terrorizmi-Univeristeti parë privat ,FON”-Shkup 2010 
defending and advancing the security situation, with an emphasis in the protection of the citizens and their personal safety and property. From what we discussed earlier we can easily conclude that the higher the level of the security situation within the state, the harder the potential for higher criminality and other criminal deviations in the society.

\section{Bibliography}

[1] Bashkim Dr Selmani, ,Krimi i oganizuar dhe Terrorizmi”, Shkup, 2009.

[2] Majk Megvaer \& Rod Morgan \& Robert Rajner ,, Teksti i Oksfordit për Kriminologji” Shkup, Nampres ,2010.Hanson, R.K., Steffy, R.A., \& Gauthier, R. (1993) „,Recedivizmi afatgjatë i ngacmuesve të fëmijëve. Gazeta e Psikologjisë këshilluese dhe klinike" 61,646-652.

[3] Ragip Dr. Halili, ,,Kriminologjia”, Prishtinë, 2011.

[4] Raporti mbi gjendjen e krimit të organizuar dhe krimit ekonomik në Europën Juglindore, Aktivitetet Kriminale- Trafikimi i Drogës www.europol.eu.int ,Europol, Fact sheet on Trafficking in Human Beings”, 2005

[5] Edmont Dragoti ,, Psikologjia ligjore e krimit” faq. 76-79 Tiranë,2007

[6] Kodi Penal i Republikës së Kosovës.

[7] Ligji Nr.8610, datës 17.05.2000, "Për parandalimin e pastrimit të parave.

[8] Ligji Nr.9258, datës 15.07.2004, "Për masat kundër financimit të terrorizmit"

[9] Ramadani, Ruzhdi. ,,Guidë për politikën dhe strategjinë e sigurisë kombëtare”, Tiranë, 2009

[10] Selmani, Bashkim. „Krimi i Organizuar dhe Terrorizmi Ndërkombëtar” Universiteti i parë prvat “FON” Shkup, 2009

[11] Reinares F., European Democracies against Terrorism, Governmental Policies and Intergovernmental Cooperations, 1999

[12] Sandoz Y., Swinarski C., Zinmiermann B., Commentaire des Protocoles additionnels du 8juin 1977 aux Conventions de Genevre du 12 aout 1949, 1986.

[13] Byroja Federale e Investigimit (FBI) "Rreth krimit të organizuar"

[14] Byroja Federale e Investigimit (FBI) "Krimi i organizuar në Ballkan"

[15] Qendra për Studime Strategjike dhe Ndërkombëtare „,Duke luftuar rrezikun në rritje të krimit të organizuar ndërkombëtar", 23 prill 2008

[16] Lajmet e trafikut të drogës, 20 prill 2008

[17] Kontrolli i rrezikut të krimit të organizuar në BE, 2008 (OCTA)

[18] Raporti vjetor i Europol-it, 2007

[19] HUMSEC, prezantim nga Dejan Anastasijevic ,Krimi i organizuar në Ballkanin Perëndimor”, nëntor 2006.

[20] Transparency International, Indeksi i Korrupsionit Global, 2007, 2008

[21] Jane's Sentine, "Kontrolli i riskut të vendit për Shqipërinë, Maqedoni, Mal i Zi, Serbi, Rumani, Bullgari, Kroaci".

[22] Kodi Penal i Republikës së Shqipërisë

[23] Kodi penal i Republikës së Maqedonisë

[24] Kodi penal i Kroacisë 